HISTORIA: Jurnal Pendidik dan Peneliti Sejarah, 3(2), 75-80. DOI: https://doi.org/10.17509/historia.v3i2.23560.

Available online at HISTORIA; Jurnal Pendidik dan Peneliti Sejarah
Journal homepage: https://ejournal.upi.edu/index.php/historia

\title{
HIGHER ORDER THINKING IN THE CONTENT KNOWLEDGE OF HISTORY LESSON
} IN MALAYSIA

\author{
Shakila Dahalan ${ }^{1}$, Abdul Razak Ahmad ${ }^{1}$ \& Ahmad Ali Seman ${ }^{2}$ \\ ${ }^{1}$ Faculty of Education, Universiti Kebangsaan Malaysia, Malaysia, \\ ${ }^{2}$ Faculty of Social Science, Universiti Kebangsaan Malaysia, Malaysia \\ shakila1212@gmail.com
}

To cite this article: Dahalan, S., Ahmad, A.R., \& Seman, A.A. (2020). Higher order thinking in the content knowledge of history lesson in Malaysia. HISTORIA: Jurnal Pendidik dan Peneliti Sejarah, 3(2), 75-80. https://doi.org/10.17509/ historia.v3i2.23560.

Naskah diterima : 9 Maret 2020, Naskah direvisi : 11 Mei 2020, Naskah disetujui : 11 Juni 2020

\begin{abstract}
This study investigating student's achievement on the higher order thinking content knowledge in history lesson. A total of 200 upper secondary school students were given 40 objectives questions on higher order thinking content knowledge. The higher order thinking content knowledge was analysis using SPSS 24.0. The results showed that student's application ( $\mathrm{f}=54.8$, $\%=75.1)$, analysis $(\mathrm{f}=40.8, \%=55.9)$ and evaluation $(\mathrm{f}=40.2, \%=55.0)$. The findings indicate that student's achievement on the higher order thinking content knowledge (application, analysis and evaluation) in medium level. Therefore, the findings highlight the important of teacher in improving their pedagogy of teaching and change their focusing to higher order thinking in history education.
\end{abstract}

Keywords: Content knowledge; cronbach alpha; higher order thinking skills; history lesson; Malaysia. 


\section{INTRODUCTION}

To date, education is an essential requirement for all students regardless the race. Quality in global education is the main agenda towards achieving education goal through advance knowledge and to apply it in its current state. Higher order thinking knowledge also known as Higher Order Thinking Skill (HOTS) is common amongst educators and students including history education. Albeit, history education comprises knowledge on historical events and figures, modern day history focused more towards higher order thinking skill of integrating historical contents knowledge with current situation (Edwards, 2016).

Higher Order of Thinking Skills (HOTS) requires higher abilities, such as the ability to think creatively and critically. Critical thinking is essentially reflective thinking to decide whether it is worth believing or doing, as Ennis put forward critical thinking is reasonable reflective thinking that focused on deciding what to believe or do "(Ennis, 1985: 54; 1996: 396). A critical attitude is a test or a test of assumptions about all things offered for acceptance, in order to find out whether they are in accordance with reality or not. Education that emphasizes the ability to think critically is the only education where it can truly succeed in training to become a good citizen (Sumner, 1906: p. 632-633).

Each of your scientific disciplines has made some valuable contributions to critical thinking. But for the greatest purpose of education, how to develop and learn critical thinking is the main thing if not the first although it will be discussed in other occasions (Facione, 2000). History education is a core subject which is essential for all students to pass in order to acquire Malaysia Education (SPM) certificate. Annually since 2015, Malaysia Education Ministry increases 5\% of high level questionnaires involving the level of applying, analysing, evaluating and creating. In 2018 report issued by KPM stated that there are 48,636 students have failed in obtaining Malaysia Education (SPM) certificate. This number will increase throughout the year should the issue in mastery higher order history content is not addressed in education (Khaliza Saidin et al.2016). A review is required to assess the students' progress in the knowledge of historical content higher order thinking, which includes assessments on the three tiers knowledge to apply, analyse and create. These findings will aid towards advancing history higher order thinking plan to the secondary school students.

\section{RESEARCH QUESTIONS}

1. What is the student application in higher order content knowledge achievement?

2. What is the student analysis in higher order content knowledge achievement?

3. What is the student evaluation in higher order content knowledge achievement?

\section{RESEARCH OBJECTIVES}

1. To identify student development in higher order content knowledge application.

2. To identify student development in higher order content knowledge analysis.

3. To identify student development in higher order content knowledge evaluation.

\section{METHODOLOGY}

This study is a survey study. The study correspondences were selected through simple random sampling technique. The selected sample is based on population of 20,335 students in Pahang, Malaysia. The study sample size is determined by Krejcie and Morgan (1970). The 200 students selected for the study sample are form four students from Kuantan, Pahang.

The researchers formulated the test questions that are validated by experts and verified with Cronbach Alpha co-efficient analysis through data gathering process to assess the history higher order content knowledge. The formulation of 40 test questions are based on the level of application, analysis and evaluation according to the themes in chapter 3 to 6 in form four history curriculum was analysis using SPSS 24.0. The titles include South East Asia Early civilization, the emergence of Islamic civilization and its development in Mecca, the Islamic Kingdom of Medina and the formation of Islamic Kingdom and its contributions. All items in the test questions are guided by Malaysia History Study Syllabus and Test Specifications Table (TSS). The number of questions generated by TSS is as shown in Table 1.1.

Questionnaires designed are not consistent with the circulated questions issued by the Malaysia Ministry of Education, which has given weight at the analysis level. Descriptive statistic involving frequency, percentage and mean were included in this study to reciprocate research questions that encompassed the achievement level of higher order content knowledge for applying, analysing and evaluating. 
HISTORIA: Jurnal Pendidik dan Peneliti Sejarah, 3(2), 75-80. DOI: https://doi.org/10.17509/historia.v3i2.23560.

Table 1 High Level Application, Analysis and Evaluation Test Specifications Schedule

\begin{tabular}{|l|l|l|l|}
\hline No & $\begin{array}{l}\text { Knowledge } \\
\text { Question Level }\end{array}$ & Item & $\begin{array}{l}\text { No. } \\
\text { Item }\end{array}$ \\
\hline 1. & $\begin{array}{l}\text { Application } \\
\text { thinking level }\end{array}$ & B.1.1 - B.1.8 & 8 \\
\hline 2. & $\begin{array}{l}\text { Analysis thinking } \\
\text { level }\end{array}$ & B.2.9- B.2.31 & 23 \\
\hline 3 & $\begin{array}{l}\text { Evaluation think- } \\
\text { ing level }\end{array}$ & B.3.32- B.3.40 & 9 \\
\hline & Total questions & 40 \\
\hline
\end{tabular}

\section{RELIABILITY STUDY}

Analysis on reliability measurements is computed via Cronbach Alpha co-efficient value. The ANATES4 software was used to demonstrate the application thinking level has the value of Cronbach Alpha 0.84. On other hand, analysis thinking level has the value of Cronbach Alpha 0.82 follows by evaluation thinking level with the value of Cronbach Alpha 0.80. These 40 items value exercised in the study demonstrates high reliability index and suitable to be used in the study (Pallant, 2007).

\section{DATA FINDINGS}

\section{Student Application Higher Order Content Knowledge Achievement Level}

The study questions for the application higher order content knowledge achievement consisted the content of four chapters in history. Table 2 below consists the student application content level from ( $\mathrm{f}=54.8$ and \% =75.1), which is exceptional. Referring to the item, the highest mean is the item related to the reopening event of Mecca city of $90 \%$. Meanwhile, the Islamic caliphate is the lowest mean (56.1\%) item as shown in Table 1.2.

It was identified that there are content knowledge percentage differences between historical figures and historical events. Pyc \& Rawson (2012) and VanSledright (2001) indicated that it is easier to achieve historical events knowledge in comparison to historical figures, which requires in depth knowledge of the figures characters. Analysis shows application level thinking is at positive level, which also influenced by thinking level tier (Hanifah Haris, 2015; Yen \& Halili, 2015). Application thinking level is the higher order for the lowest level. According to Edward (2016), student higher order thinking controls on the lower level is easier to dictate compared to the higher level.
Table 1.2 Application Level Content Knowledge Percentage

\begin{tabular}{|c|l|l|l|}
\hline No & \multicolumn{2}{|c|}{ Item } & \multicolumn{2}{|c|}{$\begin{array}{l}\text { Content } \\
\text { Percentage }\end{array}$} \\
\cline { 3 - 4 } & & \multicolumn{1}{|c|}{$\mathrm{f}$} & \multicolumn{1}{|c|}{$\%$} \\
\hline B.1.1 & $\begin{array}{l}\text { World early civilization } \\
\text { location }\end{array}$ & 60 & 82.1 \\
\hline B.1.2 & $\begin{array}{l}\text { The importance of river } \\
\text { in human life }\end{array}$ & 62 & 84.9 \\
\hline B.1.3 & $\begin{array}{l}\text { South East Asia Mari- } \\
\text { time Community }\end{array}$ & 65 & 89.0 \\
\hline B.1.4 & $\begin{array}{l}\text { The personality of } \\
\text { Prophet Muhammad } \\
\text { SAW }\end{array}$ & 44 & 60.2 \\
\hline B.1.5 & $\begin{array}{l}\text { Propagation of Islam by } \\
\text { Prophet Muhammad } \\
\text { SAW }\end{array}$ & 43 & 58.9 \\
\hline B.1.6 & $\begin{array}{l}\text { The event of reopening } \\
\text { of Mecca city }\end{array}$ & 66 & 90.4 \\
\hline B.1.7 & Migrate (hijrah) event & 58 & 79.4 \\
\hline B.1.8 & Islamic Caliphate & 41 & 56.1 \\
\hline & Overall Mean & 54.8 & 75.1 \\
\hline
\end{tabular}

\section{Student Analysis Higher Order Content Knowledge Achievement Level}

Based on Table 1.3 below, it is identified that student content knowledge ( $\mathrm{f}=41.3$ and $\%=51.2$ ) is at low level. The item with the highest mean is related government maritime ( $\mathrm{f}=56$ and $\%=76.7$ ), meanwhile Angkor and Funan government economy; and propagation of Islamic religion in Mecca have the lowest mean ( $\mathrm{f}=22$ and $\%=$ 27.3).

Referring to Taksonomi Bloom, the high level analysis has become a level that is harder to realise by the student. Anderson et al. (2001) dan Hwang et al. (2018) describe a suitable learning method is required to increase the high level analysis. Analysing level thought process consists of characterisation, separation and summarisation the history content knowledge (Malaysia Education Ministry, 2014). The student is required to be able to distinguish the difference and critique the history knowledge. The level of question will be more difficult to achieve by the student if the analysed history content knowledge is higher. 
Table 1.3 The History Content Knowledge Level for Analysis Aspect

\begin{tabular}{|c|c|c|c|}
\hline \multirow[t]{2}{*}{ No } & \multirow[t]{2}{*}{ Item } & \multicolumn{2}{|c|}{$\begin{array}{l}\text { Content } \\
\text { Knowledge } \\
\text { Percentage }\end{array}$} \\
\hline & & $\mathrm{f}$ & $\%$ \\
\hline B.2.9 & Agraria Government & 22 & 30.1 \\
\hline B. 2.10 & $\begin{array}{l}\text { Angkor and Funan } \\
\text { Government Economy } \\
\text { Activities }\end{array}$ & 20 & 27.3 \\
\hline B.2.11 & Maritime government & 56 & 76.7 \\
\hline B.2.12 & Funan goverment & 49 & 61.6 \\
\hline B. 2.13 & $\begin{array}{l}\text { South East Asia early } \\
\text { empire }\end{array}$ & 45 & 67.1 \\
\hline B.2.14 & Ancient Kedah empire & 39 & 61.6 \\
\hline B.2.15 & $\begin{array}{l}\text { South East Asia early } \\
\text { empire }\end{array}$ & 43 & 53.4 \\
\hline B.2.16 & $\begin{array}{l}\text { An Imperative mon- } \\
\text { ument in South East } \\
\text { Asia }\end{array}$ & 49 & 58.9 \\
\hline B.2.17 & $\begin{array}{l}\text { Dependence of agrar- } \\
\text { ian and maritime } \\
\text { governments }\end{array}$ & 36 & 67.1 \\
\hline B.2.18 & Discovery of artifacts & 43 & 49.3 \\
\hline B.2.19 & $\begin{array}{l}\text { Malay kingdom in } \\
\text { Straits of Malacca }\end{array}$ & 36 & 58.9 \\
\hline B.2.20 & $\begin{array}{l}\text { The early concepts of } \\
\text { royal deties in South } \\
\text { East Asia }\end{array}$ & 49 & 67.1 \\
\hline B.2.21 & $\begin{array}{l}\text { Arabian community } \\
\text { before Islam }\end{array}$ & 47 & 64.3 \\
\hline
\end{tabular}

\begin{tabular}{|l|l|l|l|}
\hline B.2.22 & $\begin{array}{l}\text { The early stages of } \\
\text { the spread of Islam in } \\
\text { Mecca }\end{array}$ & 46 & 63.0 \\
\hline B.2.23 & $\begin{array}{l}\text { Prophet Muhammad } \\
\text { SAW companions }\end{array}$ & 43 & 58.9 \\
\hline B.2.24 & $\begin{array}{l}\text { Propagation of Islamic } \\
\text { religion in Mecca }\end{array}$ & 46 & 63.0 \\
\hline B.2.25 & Badr War & 20 & 27.3 \\
\hline B.2.26 & $\begin{array}{l}\text { Early history of islamic } \\
\text { development in Mecca }\end{array}$ & 51 & 69.8 \\
\hline B.2.27 & $\begin{array}{l}\text { Migration event of } \\
\text { Prophet Muhammad } \\
\text { SAW to Mecca }\end{array}$ & 51 & 69.8 \\
\hline B.2.28 & Medina sealed & 54 & 73.9 \\
\hline B.2.29 & $\begin{array}{l}\text { Hudaibiyah Agreement } \\
\text { conditions }\end{array}$ & 30 & 41.0 \\
\hline B.2.30 & $\begin{array}{l}\text { The importance of Hu- } \\
\text { daibiyah agreement }\end{array}$ & 28 & 38.5 \\
\hline B.2.31 & Reopening Mecca city & 37 & 50.6 \\
\hline & Overall Mean & 41.3 & 51.2 \\
\hline
\end{tabular}

\section{Student Evaluation Higher Order Content Knowledge Achievement Level}

The higher order evaluation also demonstrates a low level $(f=40.2$ and $\%=55.0)$. Refer to the item question, the highest mean $(\mathrm{f}=58$ and $\%=79.4)$ is an item related to Ancient Kedah empire. Meanwhile, the item question with the lowest mean is Turki Uthmaniyah contributions. The details on the mean level are shown in Table 1.4 below.

Based on the analysis by Ministry of Education (2018), the least popular subject in students' examination question is related to Islamic kingdom formation and its' contributions. One of the reasons of which this is the least popular subject amongst the students is due to the role figures name and year (Ministry of Education, 2018) 
HISTORIA: Jurnal Pendidik dan Peneliti Sejarah, 3(2), 75-80. DOI: https://doi.org/10.17509/historia.v3i2.23560.

Table 1.4 The History Content Knowledge Level for Evaluation Aspect

\begin{tabular}{|l|l|l|l|}
\hline No & \multirow{2}{*}{ Item } & \multicolumn{2}{|l|}{$\begin{array}{l}\text { Content Knowl- } \\
\text { edge Percentage }\end{array}$} \\
\cline { 3 - 4 } & & $\mathrm{f}$ & $\%$ \\
\hline B. 3.32 & $\begin{array}{l}\text { Ancient Kedah } \\
\text { Empire }\end{array}$ & 58 & 79.4 \\
\hline B. 3.33 & $\begin{array}{l}\text { "Jahiliah" Commu- } \\
\text { nity }\end{array}$ & 33 & 45.2 \\
\hline B. 3.34 & $\begin{array}{l}\text { Prophet Muham- } \\
\text { mad SAW migra- } \\
\text { tion }\end{array}$ & 54 & 73.9 \\
\hline B. 3.35 & $\begin{array}{l}\text { Reopening event of } \\
\text { Mecca city }\end{array}$ & 37 & 50.6 \\
\hline B. 3.36 & Bani Umaiyah & 44 & 60.2 \\
\hline B. 3.37 & $\begin{array}{l}\text { Turki Uthmaniyah } \\
\text { Empire arts culture }\end{array}$ & 38 & 52.0 \\
\hline B. 3.38 & $\begin{array}{l}\text { Turki Uthmaniyah } \\
\text { Empire success }\end{array}$ & 41 & 56.1 \\
\hline B. 3.39 & $\begin{array}{l}\text { Turki Uthmaniyah } \\
\text { Empire contribu- } \\
\text { tions }\end{array}$ & 15 & 20.5 \\
\hline B. 3.40 & $\begin{array}{l}\text { Islamic caliphat } \\
\text { leadership }\end{array}$ & 42 & 57.5 \\
\hline Overall mean & 40.2 & 55.0 \\
\hline
\end{tabular}

\section{CONCLUSION}

The study indicated that application aspect for the level of history content knowledge is at a high level. Meanwhile, both analysis and evaluation aspects are at a low level. Conclusively, the history content knowledge for all three aspects are at mediocre/medium level. Knowledge contents involving historical role figures indicate lower level of mastery amongst the students in comparison to historical events contents. A suitable teaching is required to address the low-level mastery historical knowledge content especially question related to analysis and evaluation thinking level (Dunlosly et al. 2013). This due to the existing teaching/pedagogy practised by teachers can only enhance the mastery of low-level content which is application (Shakila Che Dahalan et al., 2018; Swart, 2017; Zenisky et al., 2014). The ability to master historical content in history education will be able to polish the students' historical minds.

\section{REFERENCES}

Anderson, L.W., Krathwohl, D.R.. \& Bloom, B.S. (2001). A Taxonomy for learning, teaching and assessing. New York: Longman Publishing.

Dunlosky, J., Rawson, K.A., Marsh, E.J., Nathan, M.J. \& Willingham, D.T. (2013). Improving students' learning with effective learning techniques: promising directions from cognitive and educational psychology. Psychological Science in the Public Interest, Supplement, 14(1): 4-58.

Edwards, L. (2016). Education, technology and higher order thinking skills. AARE Conference 1-18.

Ennis, R. H. (1992). "The degree to which critical thinking is subject specific: Clarification and needed research", dalam S. P. Norris (ed.), The generalizability of critical thinking: multiple perspectives on an educational ideal, pp. 21-37. New York: Teachers College Press, Columbia University.

Ennis, R. H. (1996). Critical thinking. Upper Saddle River, NJ: Prentice Hall.

Facione, N. (2000). Critical thinking and clinical judgment. Available on-line from California Academic Press: http://www.calpress.com/resource.html.

Facione, P. (1998). Critical thinking: what it is and why it counts. Available on-line from California Academic Press: http://www.calpress.com/resource.html.

Hanifah Haris, A. (2015). Aplikasi kemahiran berfikir aras tinggi (KBAT) dalam kurikulum sejarah tingkatan empat. Simposium Janji Sejarah: Asas Berfikiran Aras Tinggi

Hwang, G.J., Lai, C.L., Liang, J.C., Chu, H.C. \& Tsai, C.C. (2018). A long-term experiment to investigate the relationships between high school students' perceptions of mobile learning and peer interaction and higher-order thinking tendencies. Educational Technology Research and Development, 66(1), 75-93.

Kementerian Pendidikan Malaysia. (2014). Kemahiran berfikir aras tinggi: Aplikasi di sekolah. Putrajaya: Bahagian Pembangunan Kurikulum.

Kementerian Pendidikan Malaysia. 2018a. Pengumuman analisis keputusan Sijil Pelajaran Malaysia 2018. Putrajaya.

Kementerian Pendidikan Malaysia. (2018b). Kertas soalan peperiksaan sebenar Sejarah SPM 2012-2018. Kuala Lumpur: Lembaga Peperiksaan Malaysia.

Khaliza Saidin, Mohd Hassani Dali \& Abdul Said Ambotang. (2016). Peranan guru cemerlang Malaysia di sekolah. Jurnal Pusat Penataran Ilmu \& Bahasa, 24, 161-177.

Krejcie, R. V \& Morgan, D. (1970). Determining sample size for research activities. Educational and Psycological Measurement, 30, 607-610. 
Pallant, J. (2007). SPSS Survival Manual: A step by step guide to data analysis using SPSS for Windows (Version 10). Edisi ke-3th. New York: Mc Graw Hill.

Pyc, M.A. \& Rawson, K.A. (2012). Why is test-restudy practice beneficial for memory? An evaluation of the mediator shift hypothesis. Journal of Experimental Psychology: Learning Memory and Cognition, 38(3), 737-746.

Shakila Che Dahalan, Abdul Razaq Ahmad \& Mohd Mahzan Awang. (2018). Peningkatan pencapaian dalam mata pelajaran sejarah melalui teknik elaborative interrogation: satu sorotan kajian. Proceeding of International Conference on The Future of Education hlm. 246-263

Sumner, W.G. (1906). Folkways: A study of the sociological importance of usages, manners, customs, mores, and morals. Universitas Michigan: Ginn.
Swart, R. (2017). Purposeful use of technology to support critical thinking. JOJ Nurse Health Care Vol. 4 https://juniperpublishers.com/jojnhc/pdf/ JOJNHC.MS.ID.555626.pdf [14 September 2018].

Van Sledright, B.A. (2001). From empathic regard to self-understanding: Im/positionality, empathy, and historical contextualization. Dlm. Davis, O.L., Yeager, E.A. \& Foster, S.J. (pnyt). Historical empathy and perspective taking in the social studies hlm. 5168. USA: Rowman and Littlefield.

Yen, T.S. \& Halili, S.H. (2015). Effective Teaching of Higher-Order Thinking ( HOT ) in Education 3(2): 41-47.

Zenisky, A.L., Keller, L.A. \& Wang, X. (2014). Deconstructing constructs: Evaluating stability of higherorder thinking across technology-rich Scenarios. In Annual meeting of NCME, Philadelphia, PA. 